\begin{tabular}{|ll|}
\hline Received & $: 15$ Maret 2020 \\
Revised & $: 2$ April 2020 \\
Accepted & $: 20$ April 2020 \\
Online & $: 25$ April 2020 \\
Published & $: 30$ April 2020 \\
\hline
\end{tabular}

\title{
Analysis of Chemical Laboratory Management at SMAN 55 Jakarta
}

\author{
Amelia Sabella ${ }^{1}$, Hilman Syafei ${ }^{1}$, Umi Habibah ${ }^{2, a)}$, Rahma Rosaliana \\ Saraswati $^{3}$ \\ ${ }^{1}$ Kimia, Universitas Negeri Jakarta \\ ${ }^{3}$ Hubungan Masyarakat, Universitas Negeri Jakarta \\ ${ }^{3}$ Pendidikan Matematika, Universitas Negeri Jakarta \\ : ${ }^{a)}$ umayrahb11@gmail.com
}

\begin{abstract}
An understanding of laboratory management is highly important to be owned by parties related to the laboratory, both directly and indirectly. Laboratories must be managed and utilized properly, because chemical laboratories are one type of laboratory that is considered quite dangerous in the context of carrying out education, research, and / or community service. This study aims to describe the management of a chemical laboratory using qualitative descriptive research methods. Research subjects were the principal, vice chairman of the curriculum, chair of the laboratory, and teachers in the field of chemistry studies. Data collection techniques are observation, interviews, and documentation. The results of the research are: 1) Planning of chemical laboratory work program has been prepared and standardized by the head of the laboratory, 2) Organizing the laboratory structurally already exists, 3) Organizing by the principal involving all those involved in laboratory management, 4) The implementation of the program is suitable with the plan of the work program, 5) Supervision and evaluation of the principal must still be carried out intensively. In other words, laboratory management at SMA 55 Jakarta has been well organized.
\end{abstract}

Keywords: Chemistry, Laboratory, Management.

\section{INTRODUCTION}

Currently learning is centered on students (student-centered) which are used as an approach in the learning process. According to Oemar (2008), states that learning is a combination that is composed including human elements, materials, facilities, equipment and procedures that influence each other in achieving learning objectives. Learning is essentially a process of interaction between students and their environment so that changes in behavior happen for the better. Many factors affect the learning process, both internal and external factors. According to Mulyasa (2007) the most important task of educators is to condition the environment in order to support behavior change for students. Learning activities are directed to empower all potentials possessed by students. It is hoped that students will have competence through efforts to grow and develop attitude, knowledge, and skills.

In a book written Hosnan (2014) states that the qualities that must be realized include creativity, independence, cooperation, solidarity, leadership, empathy, tolerance and life skills of students to shape the character and improve civilization and national dignity. Therefore, to develop the affective, cognitive, and skill domains and increase the potential of students it is not enough to only rely on learning in the classroom (Bakri, 2019, Sumardani, 2019), but it needs to be supported by learning outside the classroom, both in the form of virtual simulation activities (Sumardani, 2020; Bakri, 2019), for example in chemical laboratory (Lynden-Bell, 
2007) and physics laboratory (Bakri, 2019), and directed activities in the form of practicum and experimentation in laboratory (Sumardani, 2020). These activities are usually carried out in the laboratory.

The laboratory is a place to carry out practical activities that support learning in the classroom, including workshops/workshops, experimental fields, studios, and studios. School laboratories are a means of learning as an effort to increase students' understanding of the application of facts, concepts, and principles through scientific experiments. The importance of the existence of laboratories as a learning tool for students can determine the quality of learning outcomes. To support the learning process, special attention is needed in managing the laboratory where it must be served by competent school laboratories, complete equipment, and good management. Lack of knowledge and experience from laboratory personnel is often an obstacle in laboratory management (Marlina, 2016).

Thus, special training and upgrading regarding the management of chemical laboratories are necessary to produce reliable laboratory personnel. Improper laboratory management can cause the laboratory to become a dangerous place for students so that work accidents and fatal damage can occur later, especially the chemical laboratory.

\section{METHODS}

This research uses a descriptive method using a qualitative approach referring to the results of the research method (Wiersma \& Jurs, 2005) because in this study researchers obtained information about laboratory management and its use in learning chemistry at SMA Negeri 55 Jakarta. In addition, this study emphasizes data collection to describe the actual situation that occurs from qualitative data. The subject of this research was a chemistry laboratory at SMA Negeri 55 Jakarta. In the process of data retrieval, research instruments were used in the form of interviews with the head of Jakarta 55 Public High School, head of the laboratory, and teachers in the field of chemistry studies. In addition, to complete the data also used direct observation of the chemistry laboratory of SMA Negeri 55 Jakarta. Data collection techniques in this study were by conducting interviews with the head of the Jakarta 55 High School, the head of the 55 Jakarta High School laboratory and the chemistry study teacher and directly observing the chemistry laboratory of the 55 Jakarta High School as the research subject. The data analysis technique used in this study is qualitative analysis. According to Miles and Huberman (1994: 23) descriptive qualitative analysis consists of four interacting components, namely data collection, data reduction, data presentation, and withdrawal. The instrument that was created was used in data collection at SMA Negeri 55 Jakarta. Data generated from research in the form of qualitative data are presented in the form of descriptions according to the actual situation related to the management of the laboratory in the school.

\section{RESULT AND DISCUSSION}

\section{Result}

In general, the planning of chemical laboratory work programs, namely: the planning of chemical laboratory work programs in SMA 55, Jakarta, has been systematically arranged. There are coordination and cooperation between the school principal and the representatives of facilities and infrastructure, the head of the laboratory and the chemistry teacher in compiling work programs both short-term work programs and long term work programs.

The chemical laboratory of SMAN 55 Jakarta has not made a plan about work safety in the laboratory resulting from research on organizing a chemical laboratory, namely: organizing a chemical laboratory structurally consisting of the head of the science laboratory and the person in charge. The organizational structure is posted in the chemistry laboratory with the structure of the principal, head of the laboratory, and the responsibility of the chemistry laboratory.

Results of research on the implementation of chemical laboratory work programs, namely: all administrative activities such as: making card stock material, filling card stock material, making labels on tools and materials, making the format of borrowing / using tools and materials, as well as labeling chemicals in laboratories carried out by the head of the laboratory, have not been done thoroughly. The process of procuring practicum modules in the chemistry laboratory does not yet exist so the teacher prepares the modules himself in the implementation of the practice.

The results of research on Supervision and evaluation in the implementation of the chemical laboratory work program that is carried out supervision by the head of SMA 55 Jakarta in managing the chemical laboratory. The principal never sanctions if laboratory personnel does not carry out their duties properly. The principal only gives a warning. Evaluation is done twice a year.

e-Journal : http://ejurnal.kpmunj.org 
According to Kemendikbud (2007), chemical laboratory are equipped with facilities and infrastructure as listed in table 1. Supporting factors in the management of chemical laboratories at SMA Negeri 55 Jakarta is the availability of tools and materials in chemical laboratories. The obstacles in the management of chemical laboratories at SMA Negeri 55 Jakarta are the absence of laboratory technicians, the absence of fire extinguishers, and lack of air circulation.

\section{Discussion}

Planning is a process for determining design. According to Yusuf (2009), educational planning has an important role and is at an early stage in the process of education management, which is used as a guide for the implementation, control, and supervision of the implementation of education. Planning can also be interpreted by a systematic thought process about the activities that must be carried out, the steps, methods, human resources, manpower and funds needed to achieve the specified goals effectively and efficiently. The results of the research show that the planning of a chemical laboratory at SMA Negeri 55 Jakarta has been prepared and standardized in a work program contained in the vision, mission, and goals. The laboratory work program is prepared by the head of the laboratory and approved by the school principal and is socialized at the beginning of each semester and evaluations are conducted at the end of the semester or twice a year.

The determination of personnel in the organization of chemical laboratories is carried out at the beginning of the meeting of the new school year. Personnel who are directly involved in the implementation of laboratory management, namely: school committee, school principal, head of the laboratory, chemistry study teacher. According to (Sudaryanto, 1998) laboratory organization is a system of the collaboration of groups of people, goods, or certain units about laboratories to achieve goals. Organizing a chemical laboratory means arranging a group of people or officers and other resources to carry out a plan or work program to achieve the stated goals. Whereas according to (Torang, 2014) organizations are consciously coordinated social entities, consisting of two or more people with relatively identified boundaries that function sustainably to achieve a common set of goals.

Implementation is an action of a plan that has been prepared carefully and in detail. So, simply, implementation can be applied. Through implementation, deviations will be minimized and make it easier for management to evaluate.

After reviewing the results of the interview, the head of the laboratory checks the tools and materials regularly at the end of the semester, while the chemistry teacher usually checks the tools and materials before the practicum is carried out in the laboratory. Systematic reporting on this matter will be submitted to the person in charge of the deputy head of the field of facilities and infrastructure and then forwarded to the head of SMA Negeri 55 Jakarta.

According to Kemendikbud (2007), chemical laboratory are equipped with facilities is listed in Table 1.

TABLE 1. Types, ratios, and descriptions of chemical laboratories

\begin{tabular}{|c|c|c|c|}
\hline No & Type & Ratio & Description \\
\hline 1 & Furniture & & \\
\hline 1.1 & Chair & $\begin{array}{l}1 \text { unit / student, and } \\
1 \text { unit / teacher }\end{array}$ & Strong, stable and easy to move. \\
\hline 1.2 & Workbench & 1 unit/ & Strong and stable. \\
\hline & & 7 students & $\begin{array}{l}\text { Adequate size to accommodate participant } \\
\text { activities } \\
\text { educate in groups of up to } 7 \text { people. }\end{array}$ \\
\hline 1.3 & Demonstration table & 1 unit/lab & $\begin{array}{l}\text { Strong and stable. } \\
\text { The size of the table allows for demonstrations } \\
\text { and holds the equipment and materials needed. } \\
\text { Height of the table allows all students to } \\
\text { observe the experiments } \\
\text { demonstrated. }\end{array}$ \\
\hline
\end{tabular}




\begin{tabular}{|c|c|c|c|}
\hline No & Type & Ratio & Description \\
\hline 1.4 & Preparation table & $1 \mathrm{unit} /$ lab & $\begin{array}{l}\text { Strong and stable. } \\
\text { Adequate size for preparing experimental } \\
\text { material. }\end{array}$ \\
\hline 1.5 & Tool cabinet & 1 unit/lab & $\begin{array}{l}\text { Closed and can be locked. Adequate size for } \\
\text { hold all tools. }\end{array}$ \\
\hline 1.6 & Cupboard material & 2 units/lab & $\begin{array}{l}\text { Strong and stable. } \\
\text { Enough to store all ingredients, not easy to rust, } \\
\text { the shelf is firmly propped up. } \\
\text { Sliding, locked door. }\end{array}$ \\
\hline 1.7 & Hood & 1 unit/lab & $\begin{array}{l}\text { Minimum size of space in a cupboard } \\
0.9 \mathrm{~m} \times 0.6 \mathrm{~m} \times 0.9 \mathrm{~m} \text {. The height of the work } \\
\text { area from the floor is } 70 \mathrm{~cm} \text {. } \\
\text { Material is stainless, acid resistant, has glass } \\
\text { doors that can be partly opened and closed, has } \\
\text { good lighting, } \\
\text { the gas discharge channel goes straight out and } \\
\text { pumped up, } \\
\text { have clean water channels and } \\
\text { outcast. }\end{array}$ \\
\hline 1.8 & Washtub & $\begin{array}{l}1 \text { unit / } 2 \text { groups and } \\
1 \text { unit in the } \\
\text { preparation room }\end{array}$ & Clean water is available in sufficient quantities. \\
\hline 2 & Educational Equipment & & \\
\hline 2.1 & Bottle of substance & $\begin{array}{l}\text { Each of } 24 \text { units / } \\
\text { lab }\end{array}$ & $\begin{array}{l}\text { Bertutup. } \\
\text { Volume: } 100 \mathrm{ml}, 250 \mathrm{ml} \text {, dan } \\
500 \mathrm{ml} .\end{array}$ \\
\hline 2.2 & Drop pipette & 100 units/lab & $\begin{array}{l}\text { Long tip, with rubber. } \\
20 \mathrm{~cm} \text { in size. }\end{array}$ \\
\hline 2.3 & Stirring bar & $\begin{array}{l}\text { Each of } \\
25 \text { units/lab }\end{array}$ & $\begin{array}{l}\text { Diameter: } 5 \mathrm{~mm} \text { and } 10 \mathrm{~mm} \text {, } \\
20 \mathrm{~cm} \text { long. }\end{array}$ \\
\hline 2.4 & Beaker glass & $\begin{array}{l}\text { Each of } \\
12 \text { units/lab }\end{array}$ & $\begin{array}{l}\text { Volume: } 50 \mathrm{ml}, 150 \mathrm{ml} \text {, and } \\
250 \mathrm{ml} .\end{array}$ \\
\hline 2.5 & Beaker glass & Each of 3 units/lab & $\begin{array}{l}\text { Volume: } 500 \mathrm{ml}, 1000 \mathrm{ml} \text {, and } \\
2000 \mathrm{ml} .\end{array}$ \\
\hline 2.6 & Erlenmeyer & 25 units/lab & Volume $250 \mathrm{ml}$ \\
\hline 2.7 & Volumetric flask & $\begin{array}{l}\text { Each of } \\
50,50, \text { and } 3 \\
\text { units/lab }\end{array}$ & $\begin{array}{l}\text { Volume: } 50 \mathrm{ml}, 100 \mathrm{ml} \text {, and } \\
1000 \mathrm{ml} .\end{array}$ \\
\hline 2.8 & Volume pipette & $\begin{array}{l}\text { Each of } 30 \\
\text { units/lab }\end{array}$ & $\begin{array}{l}\text { Permanent scale. } \\
\text { Volume: } 5 \mathrm{ml} \text { and } 10 \mathrm{ml} .\end{array}$ \\
\hline 2.9 & Life-sized pipette & $\begin{array}{l}\text { Each of } 30 \\
\text { units/lab }\end{array}$ & $\begin{array}{l}\text { Permanent scale. } \\
\text { Volume: } 10 \mathrm{ml}, 25 \mathrm{ml} \text {, and } 50 \mathrm{ml} .\end{array}$ \\
\hline 2.10 & Funnel & $\begin{array}{l}\text { Each of } 30 \text { and } 3 \\
\text { units/lab }\end{array}$ & Diameter: $5 \mathrm{~cm}$ and $10 \mathrm{~cm}$. \\
\hline 2.11 & Mortar & $\begin{array}{l}\text { Each of } 6 \text { dan } 1 \\
\text { units/lab }\end{array}$ & $\begin{array}{l}\text { Ceramic material, glazed inside. } \\
\text { Diameter: } 7 \mathrm{~cm} \text { and } 15 \mathrm{~cm} .\end{array}$ \\
\hline 2.12 & Spray bottle & $15 \mathrm{buah} / \mathrm{lab}$ & $\begin{array}{l}\text { Bahan plastik lentur. } \\
\text { Volume } 500 \mathrm{ml} .\end{array}$ \\
\hline 2.13 & Graduated Cylinder & $\begin{array}{l}\text { Each of } 15,15,15, \\
3, \text { and } \\
3 \text { units/lab }\end{array}$ & $\begin{array}{l}\text { Volume: } 10 \mathrm{ml}, 50 \mathrm{ml}, 100 \mathrm{ml} \text {, } \\
500 \mathrm{ml} \text {, and } 1000 \mathrm{ml} .\end{array}$ \\
\hline
\end{tabular}




\begin{tabular}{|c|c|c|c|}
\hline No & Type & Ratio & Description \\
\hline 2.14 & Burette + clamp & 10 units/lab & $\begin{array}{l}\text { Permanent scale, } \\
\text { hand burette clamps easily } \\
\text { actuated, class B. Volume } 50 \mathrm{ml} \text {. }\end{array}$ \\
\hline 2.15 & Stative and clamps & $\begin{array}{l}\text { Each of } 10 \\
\text { units/lab }\end{array}$ & $\begin{array}{l}\text { Iron, stainless, stable, strong, smooth } \\
\text { surface. } \\
\text { Boss clamp clamps. }\end{array}$ \\
\hline 2.16 & Watch glass & 10 units/lab & Diameter $10 \mathrm{~cm}$. \\
\hline 2.17 & Split funnel & 10 units/lab & $\begin{array}{l}\text { Glass material. } \\
\text { Volume of } 100 \mathrm{ml} .\end{array}$ \\
\hline 2.18 & Distillation tool & 2 sets/lab & $\begin{array}{l}\text { Glass material. } \\
\text { volume of } 100 \mathrm{ml} .\end{array}$ \\
\hline 2.19 & Scale & 2 sets/lab & Accuracy of $10 \mathrm{mg}$. \\
\hline 2.20 & $\mathrm{pH}$ meter & 2 sets/lab & $\begin{array}{l}\text { Accuracy of } 0.2 \text { (analog) and } \\
0.1 \text { (digital). }\end{array}$ \\
\hline 2.21 & Centrifuge & 1 unit/lab & $\begin{array}{l}\text { Using electric power, } \\
\text { minimum } 4 \text { tubes. }\end{array}$ \\
\hline 2.22 & Barometer & 1 unit/lab & $\begin{array}{l}\text { For lab walls, equipped } \\
\text { thermometer. }\end{array}$ \\
\hline 2.23 & Thermometer & 6 units/lab & $\begin{array}{l}\text { Can measure the temperature of } 0-100^{\circ} \mathrm{C} \text {, } \\
\text { accuracy } 1{ }^{\circ} \mathrm{C} \text {, } \\
\text { does not contain mercury. }\end{array}$ \\
\hline 2.24 & $\begin{array}{l}\text { AC / DC multimeter, } \\
10 \text { kilo ohms / volt }\end{array}$ & 6 units/lab & $\begin{array}{l}\text { Can measure voltage, current and resistance. } \\
\text { Minimum current measurement limit of } 100 \mathrm{~mA} \text { - } \\
5 \mathrm{~A} \text {. } \\
\text { The minimum voltage measurement limit for DC } \\
100 \mathrm{mV}-50 \mathrm{~V} \text {. The minimum voltage } \\
\text { measurement limit } \\
\text { for AC } 0-250 \mathrm{~V} \text {. }\end{array}$ \\
\hline 2.25 & Spiritus burners & 8 units/lab & Glass material, lid. \\
\hline 2.26 & $\begin{array}{l}\text { Three feet }+ \text { gauze } \\
\text { base } \\
\text { Wire }\end{array}$ & 8 units/lab & $\begin{array}{l}\text { Height adjustable height } \\
\text { spiritus burner. }\end{array}$ \\
\hline 2.27 & Stopwatch & 6 units/lab & Accuracy of 0.2 seconds. \\
\hline 2.28 & Calorimeter & 6 units/lab & $\begin{array}{l}\text { Can provide data for reaction enthalpy } \\
\text { learning. Low material heat capacity. } \\
250 \mathrm{ml} \text { volume. }\end{array}$ \\
\hline 2.29 & Test tube & 100 units/lab & $\begin{array}{l}\text { Glass. } \\
\text { Volume: } 20 \mathrm{ml} .\end{array}$ \\
\hline 2.30 & Test tube rack & 7 units/lab & $\begin{array}{l}\text { wood. } \\
\text { Minimum capacity of } 10 \text { tubes. }\end{array}$ \\
\hline 2.31 & test tube brush & 10 units/lab & $\begin{array}{l}\text { Fuzz. } \\
\text { Diameter of } 1 \mathrm{~cm} .\end{array}$ \\
\hline 2.32 & Centrifuge tube & 8 units/lab & $\begin{array}{l}\text { Glass, size according to } \\
\text { centrifuge. }\end{array}$ \\
\hline 2.33 & $\begin{array}{l}\text { Periodic Table of the } \\
\text { Elements }\end{array}$ & 1 unit/lab & $\begin{array}{l}\text { Poster, } 220 \text { gram paper, laminate, } \\
\text { can be hung. }\end{array}$ \\
\hline 2.34 & Molecule model & 6 sets/lab & $\begin{array}{l}\text { The minimum can indicate hydrogen, oxygen, } \\
\text { nitrogen, sulfur and carbon atoms, and can } \\
\text { strung together into molecules. }\end{array}$ \\
\hline 2.35 & Experiments manual & $\begin{array}{l}6 \text { units/ } \\
\text { experiment }\end{array}$ & \\
\hline
\end{tabular}




\begin{tabular}{|c|c|c|c|}
\hline No & Type & Ratio & Description \\
\hline 3 & \multicolumn{3}{|l|}{ Educational media } \\
\hline 3.1 & White board & 1 unit/lab & $\begin{array}{l}\text { Minimum size is } 90 \mathrm{~cm} \times 200 \\
\mathrm{~cm} \text {. } \\
\text { Placed in a position that allows all students to } \\
\text { see clearly. }\end{array}$ \\
\hline 4 & \multicolumn{3}{|l|}{ Consumables } \\
\hline & \multicolumn{3}{|c|}{$\begin{array}{l}\text { Consumables available in the laboratory include chemicals, with a lot at any time } \\
1.2 \mathrm{x} \text { much needed. Chemicals include substances needed in experiments: } \\
\text { Introduction to Chemical Reactions, Techniques Separation and Purification, Acid- } \\
\text { Base Titration, Electrochemistry, Energetics, Manufacturing of Applied Chemical } \\
\text { Knowledge Products }\end{array}$} \\
\hline 5 & Others & & \\
\hline 5.1 & Electrical socket & 9 units/lab & $\begin{array}{l}1 \text { socket for each student table, } \\
2 \text { sockets for the demo table, } \\
2 \text { sockets for the preparation room. }\end{array}$ \\
\hline 5.2 & Fire extinguisher & 1 unit/lab & Easy to operate. \\
\hline 5.3 & First aid kit & 1 unit/lab & $\begin{array}{l}\text { Consist of first aid kit and its contents are not } \\
\text { expired including first aid medicine for burns } \\
\text { and wounds } \\
\text { open. }\end{array}$ \\
\hline 5.4 & Trash can & 1 unit/lab & \\
\hline 5.5 & Wall clock & 1 unit/lab & \\
\hline
\end{tabular}

The table above is an indicator of the Kemendikbud regarding a good chemistry laboratory. The interview revealed that the monitoring and evaluation process was carried out twice a year with details at the end of each semester. According to Mrs. Nidaa as the person in charge of chemical laboratories as well as chemistry teachers at SMA Negeri 55 Jakarta that the recent evaluation found that the availability of tools and materials in the laboratory reached $92 \%$ and according to Mr. Nelson Sirait as the head of the chemistry laboratory the laboratory feasibility level reached $70 \%$.

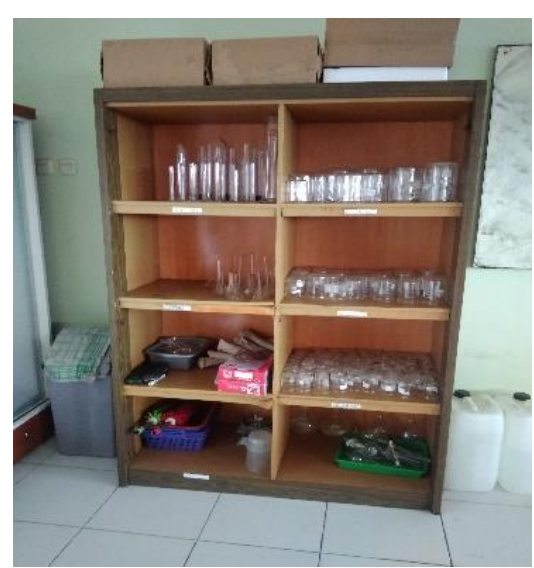

FIGURE 1. Medium-Scale wooden glass cabinet

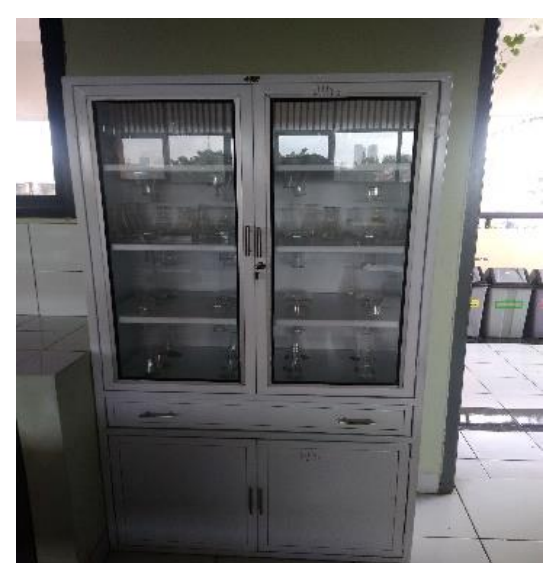

FIGURE 2. Medium-Scale stainless steel glass cabine 


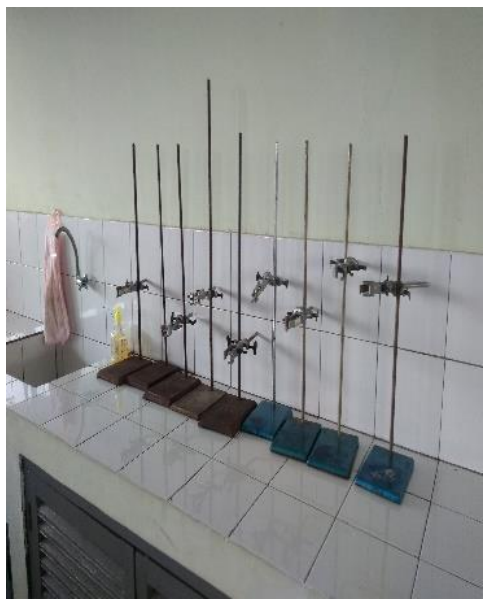

FIGURE 3. Practicum Table And Stative

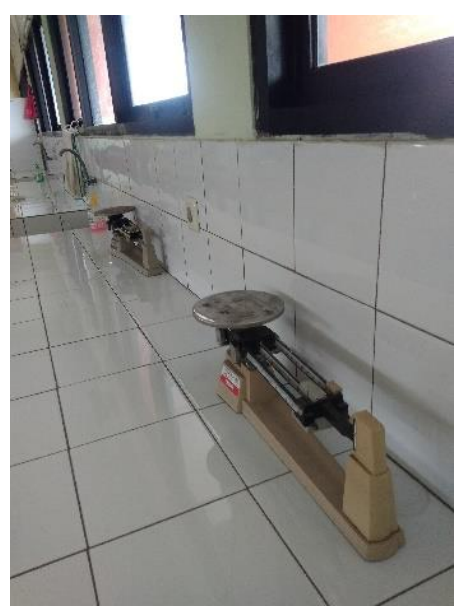

FIGURE 5. Practical Table and Scale

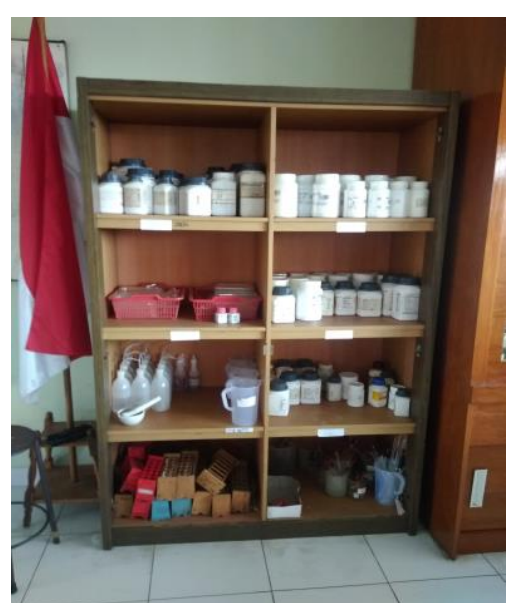

FIGURE 7. The Chemical Storage Cabinet

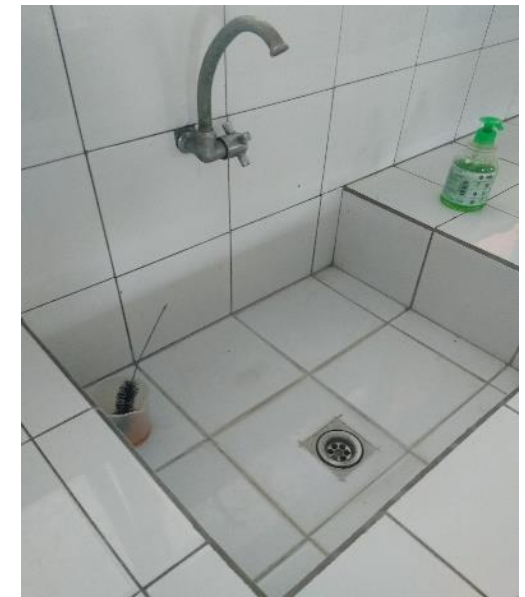

FIGURE 4. Tool Washbasins

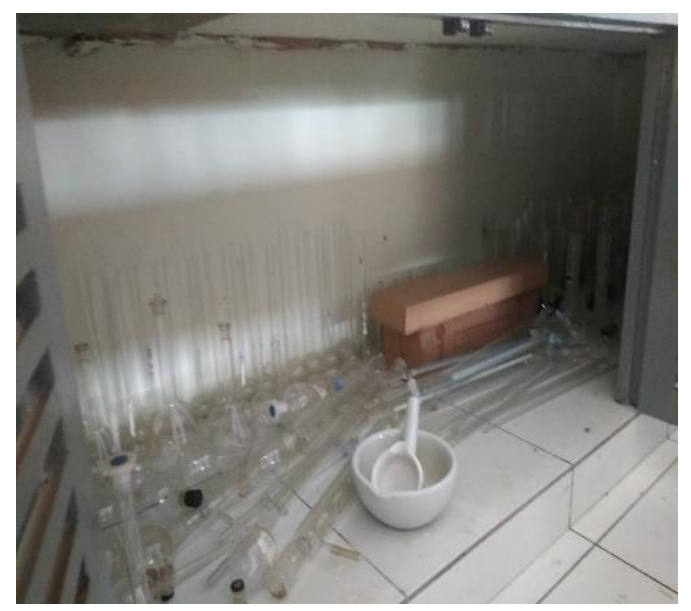

FIGURE 6. The Drawer under The Practicum Table

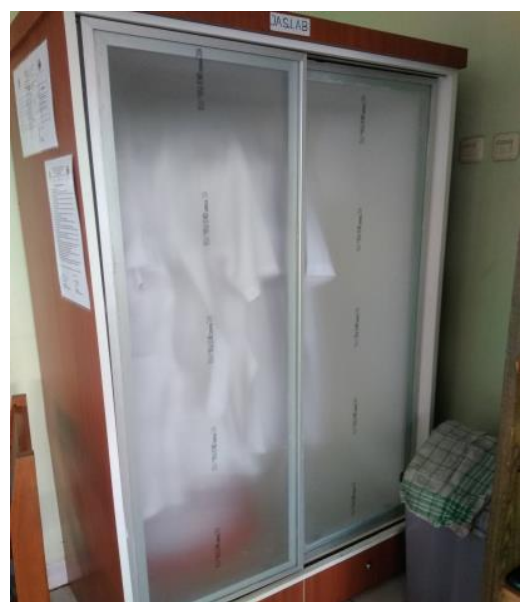

FIGURE 8. PPE Storage Cabinets 


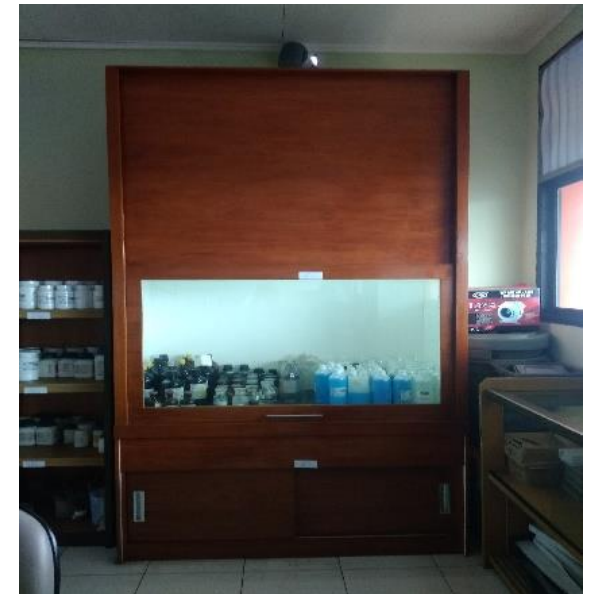

FIGURE 9. Acid Cabinets

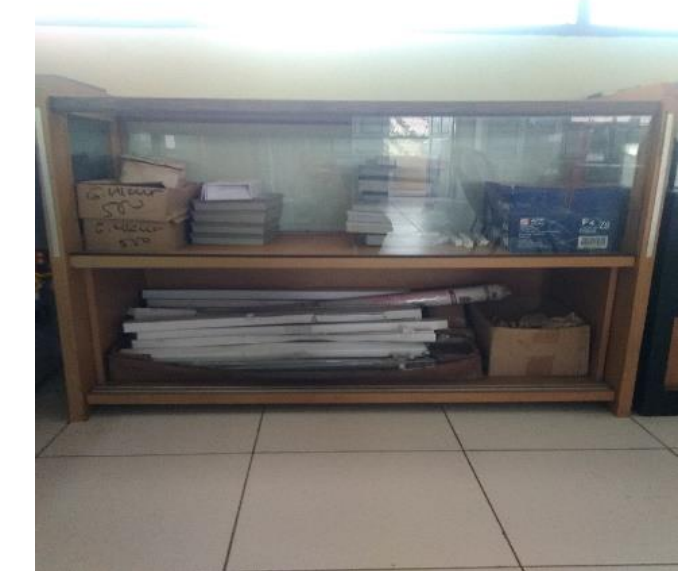

FIGURE 10. Wooden Cabinet for Tool Storages

The results of research conducted by researchers supporting factors in managing chemical laboratories are the availability of adequate tools and materials. Appropriate tools and materials can facilitate the work of chemistry subject teachers in explaining practicum to students.

Other research results are found that the absence of laboratory staff is an inhibiting factor in the management of chemical laboratories because all the main tasks and functions (tupoksi) of the laboratory assistant must be done indirectly by the head of the laboratory and subject teachers when carrying out practicum activities. Other inhibiting factors are the absence of APAR in the laboratory and lack of air circulation.

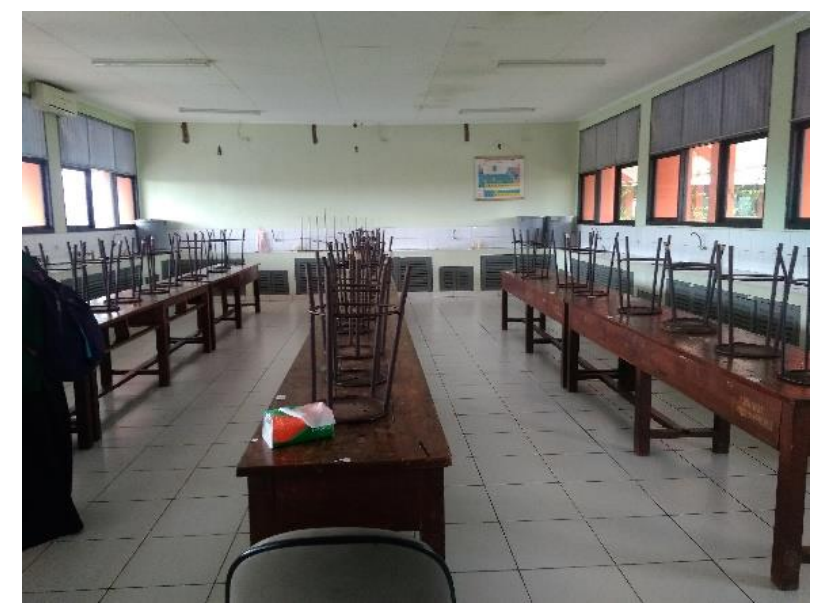

FIGURE 11. The Condition of Air Vents in The laboratory Room

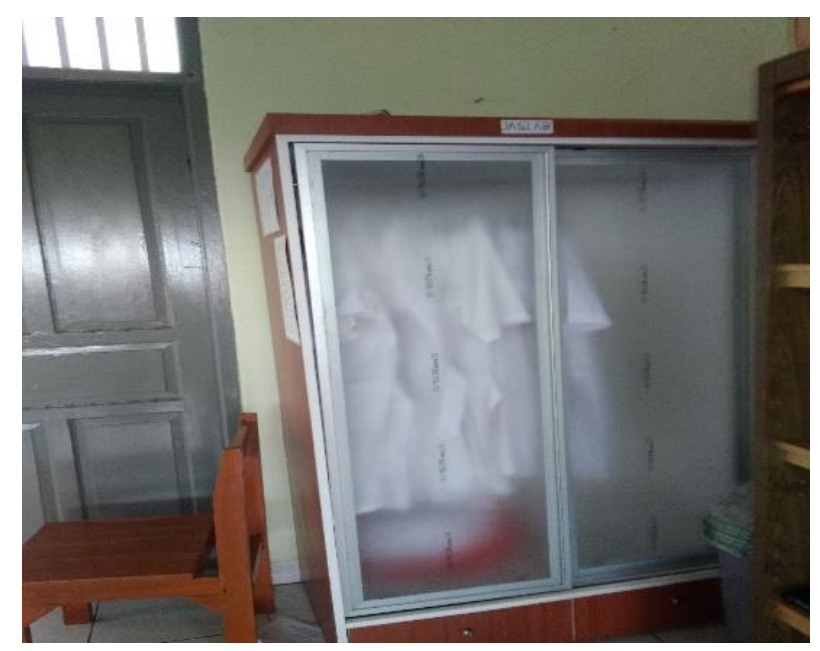

FIGURE 12. The Condition in the Corner of the Lab That Doesn`t yet have a Fire Extinguisher. 
In the Regulation of the Minister National Education of the Republic of Indonesia in the laboratory it is explained that there must be a medium or large-scale glass tools as shown in Figure 1, Figure 2 and Figure 10, then there is a practicum table and a stative device along with clamp clamps in the Figure 3 and scale to measure mass from a substance such as the balance sheet in Figure 5, then there is a sink as a place for washing tools and disposal of waste materials or waterways as in Figure 4, after that there is a wooden cabinet as a chemical storage area in Figure 7 or storage of personal protective equipment in Figure 8 and the fume hood in Figure 9, then in Figure 11 and Figure 12 show the condition of the air ventilation and corner of the laboratory room that does not yet have a fire extinguisher.

According to (Ministry of National Education Directorate General of PMPTK, 2010), lack of knowledge and experience from laboratory personnel is often an obstacle in laboratory management. For this reason, it is very necessary to have special training and upgrading regarding the management of chemical laboratories so as to produce qualified laboratory personnel, especially the head of the laboratory.

\section{CONCLUSION}

From the results of chemical laboratory management research in SMA Negeri 55 Jakarta, the results show that: chemical laboratory planning has been arranged and standardized in a work program contained in the vision, mission, and goals of Jakarta 55 Public High School. The standardization of planning used refers to the Regulation of the Minister of National Education of the Republic of Indonesia Number 24 of 2007 concerning means and infrastructure standards for elementary school/madrasah ibditaiyah (SD/MI) first middle school/madrasah tsanawiyah (SMP/MTS), and middle schools/madrasah aliyah (SMA/MA), which was held in a meeting at the beginning of semester meeting to reach consensus and agreement together which subsequently serves as a mandatory policy to be obeyed by all school officials. In organizing a chemical laboratory already exists and consists of the principal, head of the laboratory, the person in charge of the chemical laboratory and the chemical laboratory. The checking of chemical laboratory equipment and materials at SMA 55 Jakarta is good and is done regularly by the head of the chemical laboratory. Monitoring and evaluation on a large scale are carried out twice year by all school authorities. However, each week there will be supervision and evaluation by teachers I the field of chemical studies, especially for teachers who will use the laboratory from practicum where the availability and condition of tools and materials are checked. Thus, this is considered quite effective in laboratory supervision and evaluation. Supporting factors from the chemical laboratory at SMA Negeri 55 Jakarta is the presence of tools and chemicals that are complete and suitable for use by students at SMA Negeri 55 Jakarta. The inhibiting factors are lack of air circulation, unavailability of light fire extinguishers, and also the absence of laboratory assistants. In other words, the management of chemical laboratories at SMA Negeri 55 Jakarta is well organized.

\section{ACKNOWLEDGMENT}

With the completion of this research, we agree to thank all members of the Young Research Group of the Jakarta State University for providing motivation and assistance for carrying out this research well, smoothly and successfully.

\section{REFERENCES}

Arikunto S, Yuliana L. 2008. Manajemen Pendidikan. Yogyakarta: Aditya Media.

Bafadal I. 2003. Manajemen Peningkatan Mutu Sekolah Dasar; dari Sentralisasi Menuju Desentralisasi. Jakarta: Bumi Aksara.

Bakri F, Sumardani D, Muliyati D. (2019) Integrating Augmented Reality into Worksheets: Unveil Learning To Support Higher-Order Thinking Skills. AIP Conference Proceedings 2169(1): 020012.

Bakri F, Sumardani D, Muliyati D. (2019). The augmented reality application for simulating electromotive force concept. Journal of Physics: Conference Series 1402 (6): 066039.

Bakri F, Sumardani D, Muliyati D. (2019). The 3D simulation of Lorentz Force based on augmented reality technology. Journal of Physics: Conference Series 1402(6): 066038.

Chang R. 2000. Kimia dasar. Jakarta: Erlangga.

[Depdiknas] Departemen Pendidikan Nasional. 2003. Pedoman Khusus Pengembangan Silabus dan Penilaian Mata Pelajaran Kimia. Jakarta : Departemen Pendidikan Nasional.

[Depdiknas] Departemen Pendidikan Nasional.2003.Standar Kompeensi Mata Pelajaran kimia SMA dan MA. Jakarta: Balai Pustaka.

e-Journal : http://ejurnal.kpmunj.org 
Gunawan A H. 1996. Administrasi Sekolah; Administrasi Pendidikan Mikro. Jakarta: PT. Rineka Cipta.

Hidayat A, Machali I. 2010. Pengelolaan Pendidikan Konsep, Prinsip dan Aplikasi dalam Mengelola Sekolah dan Madrasah. Bandung: Pustaka Educa.

Lynden-Bell R M, Del-Popolo M G, Youngs T G, Kohanoff J, Hanke C G, Harper J B, \& Pinilla C C. (2007). Simulations of ionic liquids, solutions, and surfaces. Accounts of chemical research, 40(11), 1138-1145.

Marlina L. 2016. Manajemen laboratorium. Manajer Pendidikan, 10 (4): 374-380.

Sumardani D, Putri A, Saraswati R R, Muliyati D, Bakri F. (2020). Virtual Reality Media: The Simulation of Relativity Theory on Smartphone. Formatif: Jurnal Ilmiah Pendidikan MIPA 10(1): 13-24.

Sumardani D, Saraswati R R, Putri A, Bakri F, Muliyati D. (2020). System Implementation of Augmented Reality Application in Student Worksheet. Jurnal Informatika 8(1): 10-18.

Sumardani D, Wulandari A, Doriza S. (2019). Penerapan Teknologi Augmented Reality pada Media Pembelajaran Poster Tatasurya. Prosiding Seminar Nasional Fisika (E-Journal) 8: 451-456. 